// International Journal of Engineering \& Technology. 2018. 7 (4.38). P. 54-59. URL: https://sciencepubco.com/ index.php/ijet/article/view/24320.

7. Барцаева Е.В. Сущность личностного компонента готовности к социально-бытовой ориентации дошкольников // Проблемы современного педагогического образования. Сер.: Педагогика и психология: сб. науч. тр. Вып. 59. Ч. 3. Ялта: РИО ГПА, 2018. С. 67-69.

8. Барцаева Е.В. Содержание когнитивного компонента готовности к социально-бытовой ориентации дошкольников [Электронный ресурс] // Современные научные исследования. Вып. 9: сборник статей участников всерос. конкурса «Лучшая молодежная научная статья - 2018», проведенного АНО ДПО «МЦИТО», г. Киров (август 2017 - май 2018 года). Киров: Изд-во МЦИТО, 2018.

9. Барцаева Е.В., Демина М.А., Харлампова А.С. К проблеме содержания деятельностного компонента готовности к социально-бытовой ориентации дошкольников // Вестник образовательного консорциума Среднерусский университет. Серия: Гуманитарные науки. 2018. № 11. С. 12-14.

10. Барцаева Е.В. Исследование готовности к социально-бытовой ориентации детей дошкольного возраста // Теория и практика образования дошкольников с ограниченными возможностями здоровья: монография / Е.В. Золоткова [и др.]; под ред. Е.В. Золотковой. Саранск: Мордов. гос. пед. ин-т, 2018. C. $28-50$.

Статья публикуется при поддержке гранта РФФИ «А - Конкурс на лучиие проекты фундаментальных научных исследований» Формирование готовности к социально-бытовой ориентации стариих дошкольников в организациях дополнительного образования (19-013-00508/19).

\title{
THE STUDY OF SENIOR PRESCHOOLERS' READINESS FOR SOCIAL ORIENTATION IN THE ORGANIZATIONS OF ADDITIONAL EDUCATION
}

\section{(C) 2019}

Barcaeva Elena Vasilievna, senior lecturer of Special Pedagogy and Medical Basics of Defectology Department Mordovian State Pedagogical Institute named after M.E. Evseviev (Saransk, Russian Federation)

Abstract. The paper presents a technique of defining the level of development of senior preschoolers' readiness for social orientation in the organizations of additional education. It contains diagnostic tools that determine the level of development of senior preschoolers' readiness for social orientation in these organizations. The paper presents the level characteristics of the main structural components of readiness for social orientation in relation to the senior preschool age (personal, cognitive and activity): high, medium, low and unformed. To identify the level of each component development, criteria and evaluation indicators are identified, as well as methods of study, including a method of problem situations, a survey, practice-oriented tasks. With the help of the developed method the author carried out an experiment (ascertaining experiment), its results are presented in the paper. The paper describes in detail one of the components of senior preschoolers' readiness for social orientation - a personal one, including value orientations; motivational orientation; emotional well-being; integrative qualities of the individual. This component was found to be at a low level that testifies that it is necessary to develop senior preschoolers' readiness for social orientation in the organizations of additional education.

Keywords: social orientation; readiness; readiness for social orientation; senior preschoolers; components of senior preschoolers' readiness for social orientation; personal component; cognitive component; activity component; organization of additional education.

УДК 57 (07):373

DOI 10.24411/2309-4370-2019-12302

Статья поступила в редакцию 17.02.2019

\section{СОВЕРШЕНСТВОВАНИЕ СОДЕРЖАНИЯ ПОДГОТОВКИ ШКОЛЬНИКОВ К ПРАКТИЧЕСКОМУ ТУРУ РЕГИОНАЛЬНОГО ЭТАПА ВСЕРОССИЙСКОЙ БИОЛОГИЧЕСКОЙ ОЛИМПИАДЫ}

Ефимова Наталья Владимировна, доктор биологических наук, профессор кафедры общей биологии и физиологии

Шилкова Татьяна Викторовна, кандидат биологических наук, доцент кафедры общей биологии и физиологии

Соколова Татьяна Леонидовна, кандидат биологических наук, доцент кафедры общей биологии и физиологии

Южно-Уральский государственный гуманитарно-педагогический университет

(2. Челябинск, Российская Федерация)

Аннотация. Перед современной системой образования стоит задача развития и поддержки талантливой молодежи. На поиск, поддержку и сопровождение талантливых детей направлены, в частности, предметные олимпиады школьников, которые, повышая интерес обучающихся к науке, развивая их творческий потенциал и познавательную активность, способствуют профессиональной ориентации обучающихся и их жизненному успеху в будущем. Опыт проведения различных этапов Всероссийской олимпиады школьников по биологии показал, что для достижения высоких результатов участникам олимпиады необходимы методически обоснованная система тренировочных сборов и консультативная помощь специалистов в различных обла- 
Ефимова Н.В., Шилкова Т.В., Соколова Т.Л.

стях биологии. В статье обобщен многолетний опыт организации и проведения практического тура регионального этапа Всероссийской олимпиады школьников по биологии на кафедре общей биологии и физиологии ФГБОУ ВО «Южно-Уральский государственный гуманитарно-педагогический университет». Представлены методические рекомендации, направленные на совершенствование подготовки школьников к практическому туру регионального этапа Всероссийской олимпиады по биологии (кабинет «Биология человека», 9 класс), включающие характеристику типичных ошибок участников олимпиады, алгоритм выполнения практических заданий по микроскопированию гистологических препаратов, критерии дифференцирования гистологических объектов, примеры олимпиадных заданий с матрицей ответов.

Ключевые слова: Национальные образовательные инициативы; Всероссийская олимпиада школьников по биологии; практический тур олимпиады; олимпиадные практические задания по гистологии; методические рекомендации; работа с одаренными детьми; подготовка школьников к участию в предметной олимпиаде по биологии.

\section{Постановка проблемы}

Одной из центральных задач современной системы образования является развитие и поддержка талантливой молодежи, работа с одаренными и мотивированными детьми [1-8]. На поиск, поддержку и сопровождение талантливых детей направлен ряд Национальных образовательных инициатив, в частности инициатива «Наша новая школа» (2010 г.) [9], в реализации которых особое место занимают предметные олимпиады школьников. Всероссийская олимпиада школьников проводится в целях выявления и развития у обучающихся интеллектуальнотворческих способностей и интереса К научноисследовательской деятельности, пропаганды научных знаний, а также отбора лиц, проявивших выдающиеся способности по общеобразовательным предметам [10;11]. Предметные олимпиады различного уровня (от школьных до международных), повышая интерес обучающихся к науке, развивая их творческий потенциал и познавательную активность [1118], способствуют профессиональной ориентации обучающихся $[2 ; 5 ; 11]$, их карьерному росту и жизненному успеху в будущем $[19 ; 20]$.

\section{Анализ публикаций по проблеме}

Различные аспекты рассматриваемой проблемы представлены в ряде публикаций, раскрывающих вопросы истории становления олимпиадного движения [21], анализа характера теоретических и практических олимпиадных заданий, а также успешности их выполнения [2; 22-26]. Теоретический тур олимпиады школьников по биологии традиционно проводится в тестовой форме и требует от школьников умения аналитически мыслить, обобщать факты и творчески их интерпретировать [2, с. 176; 24, с. 5]. Программа теоретического тура биологической олимпиады предполагает знание школьниками большого объема фактического материала о строении и жизнедеятельности биологических систем разного уровня организации, основных закономерностей развития живой природы, важнейших биологических теорий, практических связей биологии с промышленностью, сельским хозяйством и медициной, современными проблемами охраны природы [23, с. 14]. Затруднения у учащихся вызывают вопросы на знания, выходящие за рамки школьного курса биологии, а также касающиеся специальных знаний и терминов [22, с. 64-70], в частности по генетике, цитологии, молекулярной биологии и физиологии человека.

Практический тур биологической олимпиады в зависимости от кабинета, может включать решение ситуационных задач (например, по генетике или Самарский научный вестник. 2019. Т. 8, № 2 (27) микробиологии), выполнение практической или лабораторной работы (например, по биохимии, физиологии растений, зоологии, ботанике). В качестве объектов исследования служат различные биологические объекты: гербарии, коллекции насекомых, влажные препараты (фиксированные в спирте органы растений или зоологические объекты), муляжи, микропрепараты, электронные микрофотограммы и др. Специфика заданий практического тура Всероссийской олимпиады по биологии требует от участников обладания исследовательскими умениями [27, c. 34], в частности умением постановки биологического эксперимента, проведения наблюдения, регистрации и описания результатов практической или лабораторной работы, в том числе выполнения схематических рисунков, отражающих, например, особенности структурной организации биологического объекта [26, с. 324-325; 24, с. $5 ; 25$, с. 31-32]. Таким образом на практическом туре у участников олимпиады проверяются способность к творческому мышлению, умение сравнивать и обобщать различные факты, а также комплекс специальных умений, направленных на определение и описание биологических объектов, приготовление временных микропрепаратов, микроскопирование гистологических объектов, а также навыки работы с определителями, реактивами, микроскопами, другими приборами и оборудованием. Анализ результативности на практическом туре свидетельствует о проблемах, связанных, прежде всего, с учебно-исследовательскими компетенциями участников биологических олимпиад - недостаточностью сформированности предметных умений: учащиеся затрудняются в пользовании микроскопом, не умеют готовить микропрепараты, выполнять биологические рисунки, устанавливать причинно-следственные связи, интерпретировать полученные результаты, делать обоснованные выводы и т.п. [22, с. $70-71 ; 25$, с. $32 ; 27$, с. 34-35].

Опыт проведения различных этапов Всероссийской олимпиады школьников по биологии показал, что для достижения высоких результатов большинству школьников недостаточно только самоподготовки и помощи учителя-предметника. Неоценимую помощь в подготовке школьников к участию в предметных олимпиадах может оказать методически обоснованная система подготовки, а именно методические пособия и рекомендации, кружковые и факультативные занятия, компьютерные тренажеры и дистанционные образовательные технологии, тренировочные сборы и консультативная помощь специалистов в различных областях биологии [2, с. $179 ; 11$, c. $65 ; 27$, c. $35-38 ; 28$, c. $18-19 ; 29$, c. $102-104 ; 30$, 
Ефимова Н.В., Шилкова Т.В., Соколова Т.Л.

Совершенствование содержания подготовки школьников к практическому туру..

13.00.00 - педагогические науки

c. 18-19], а также психологическое сопровождение $[21$, c. 181$]$.

Цель статьи - обобщить и проанализировать опыт проведения практического тура регионального этапа Всероссийской олимпиады школьников по биологии (кабинет «Биология человека», 9 класс) и дать методические рекомендации по совершенствованию содержания подготовки школьников к биологической олимпиаде.

\section{Основные результаты}

Южно-Уральский государственный гуманитарнопедагогический университет в течение многих лет является базовым вузом для проведения регионального этапа Всероссийской биологической олимпиады школьников в Челябинской области. Задания практического тура регионального этапа Всероссийской олимпиады школьников по биологии (кабинет «Биология человека», 9 класс) включают определение и описание гистологических объектов, представленных на микропрепаратах. Поэтому при подготовке к олимпиаде нужно уделить внимание гистологическому описанию анатомических объектов, а именно морфофункциональной характеристике структурно-функциональных единиц органов (например, ацинус легкого, нефрон почки, кишечная ворсинка, печеночная долька), тканевому составу органа с учетом общих принципов строения полостных и паренхиматозных органов. Необходимо отметить, что в состав любого анатомического органа входят нервная и соединительная ткани, выполняющие регуляторную и каркасно-трофическую функцию. Ведущей тканью, определяющей специфические функции органов, как правило, является эпителий (характерно для паренхиматозных органов), а также мышечная ткань (характерно для полостных органов и скелетных мышц) и нервная ткань (характерно для органов нервной системы).

Задания по микроанатомии (общей и частной гистологии) требуют от учащихся умения работать со световым микроскопом, навыков микроскопирования и описания гистологических препаратов. Многолетний опыт проведения олимпиад показал недостаточную подготовку (компетентность) учащихся 9 классов, а именно неумение настроить микроскоп (правильно использовать объективы, микровинт, диафрагму и конденсор), незнание стандартного набора гистологических препаратов (в том числе изучаемых в рамках школьного курса биологии), отсутствие навыков микроскопирования и описания препаратов [25, с. 32]. Базовые рекомендации по подготовке микроскопа к работе и общие правила микроскопирования гистологических препаратов [31, с. $13-14 ; 32$, с. $208-210 ; 33$, с. 16-17] включают следующее.

- Микроскопирование гистологических препаратов начинают с установки освещения микроскопа. Сложности у учащихся при подготовке микроскопа к работе возникают, если микроскоп оснащен зеркалом в качестве осветительного устройства. Необходимо четко запомнить, что вогнутую сторону зеркала используют при естественном освещении, а плоскую сторону зеркала - при искусственном освещении. Настройку освещения с целью достижения равномерного освещения поля зрения проводят при малом увеличении микроскопа (объектив $\times 8$ или $\times 20$ ) и поднятом конденсоре, при этом можно использовать ирисовую диафрагму, вмонтированную в конденсор для регуляции степени освещенности препарата.

- Световой микроскоп позволяет получить увеличенное и перевернутое изображение объекта, что необходимо учитывать при ориентации и описании гистологических микропрепаратов. Так, на гистологических срезах полостных органов (например, бронхов или кишечника) последовательно располагаются слизистая, выстланная эпителием, потом подслизистая соединительнотканная основа и далее мышечные слои.

- Световая микроскопия осуществляется путем изучения препарата в проходящем свете. Свет, излучаемый источником света (обычно электрической лампочкой), собирается линзами конденсора и, проходя через изучаемый препарат, попадает на линзы объектива, в фокальной плоскости которого формируется изображение объекта. Линзы окуляра микроскопа только увеличивают сформированное объективом изображение гистологического объекта, не добавляя к нему новых деталей. Поэтому, чтобы добиться детального рассмотрения отдельных элементов микропрепарата, необходимо изначально с помощью макровинта получить четкое изображение объекта при малом увеличении микроскопа (объективы $\times 8$ или $\times 20$ ), расположив в центр поля зрения желаемый участок препарата, а потом перейти к большому увеличению (объектив ×40) и использовать только микровинт, вращая его на пол-оборота вперед или назад.

- Конденсор, как элемент оптической части микроскопа, собирает и фокусирует свет, образуя световой фокус, освещающий исследуемый гистологический объект. При использовании большого увеличения микроскопа необходимо, как правило, поднять конденсор вплоть до соприкосновения с предметным стеклом микропрепарата, а при работе на малом увеличении конденсор следует несколько опустить.

Определение принадлежности изучаемого «слепого» гистологического препарата к основным типам тканей животных следует проводить на основе системного подхода. Ткань нужно рассматривать как биосистему, состоящую из клеток и их производных, имеющих общее происхождение, строение и функции. Исходя из этого определения, общими критериями определения тканевой принадлежности являются:

- количество (много/мало) клеток, их качественный состав (разнообразные/однотипные) и взаиморасположение (наличие изогенных групп клеток, клеточных пластов и др.);

- количество (много/мало) и состав межклеточного вещества, в том числе наличие коллагеновых и эластических волокон, их взаимное расположение (упорядоченность);

- специфика окраски гистологического препарата.

Для выполнения этого задания нужно ориентироваться на общие свойства отдельных типов тканей животных. Так, несмотря на разнообразие строения, функций и эмбриональных источников развития, для всех эпителиев характерен ряд следующих признаков $[31$, с. $60 ; 33$, с. $86 ; 34$, с. $118-119]: 1)$ эпителио- 
Ефимова Н.В., Шилкова Т.В., Соколова Т.Л.

циты объединяются в непрерывные пласты, лежащие на базальной мембране; 2) в эпителиях практически отсутствует межклеточное вещество и клетки соединены между собой и базальной мембраной множеством специальных контактов; 3) эпителиоциты обладают полярностью, в частности на апикальной поверхности клеток могут присутствовать микроворсинки или реснички; 4) эпителий не содержит кровеносных сосудов; 5) эпителии обладают высокой регенерационной способностью. Первые два признака являются наиболее значимыми для дифференциации эпителиальных тканей при микроскопировании гистологических препаратов. Определив тип ткани на микропрепарате как эпителиальный, дальнейшую дифференцировку гистологического объекта необходимо проводить, ориентируясь на такие признаки, как: однослойность/многослойность эпителия, однорядность/многорядность (в случае однослойных эпителиев), форму клеток, наличие плоского ороговевающего слоя клеток (в случае многослойного эпителия). Соединительные ткани, напротив, содержат большое количество межклеточного вещества (матрикса), которое может быть четко структурировано в виде волокнистых пучков (например, в сухожилиях) или в виде концентрических пластин (остеонов) в костной ткани.

При микроскопическом исследовании и интерпретации гистологических препаратов следует учитывать, что поскольку многие тканевые структуры толще среза, то некоторые их детали могут отсутствовать на конкретном срезе и что структуры в пределах ткани обычно попадают в срез случайно. Вид различных трехмерных тканевых структур (извитой трубки или шара) на тонких срезах может выглядеть практически одинаково [33, с. 35-36]. Многие гистологические препараты представляют собой продольный или поперечный срезы органов, на которые попадают не только отдельные ткани (например, срез спинного мозга, сердечной мышцы или сухожилия), но и комплексы разных типов тканей (например, срез стенки кишечника или трахеи, срез почки). Так, микропрепарат «Многослойный плоский ороговевающий эпителий (срез кожи пальца человека)» включает не только эпидермис, но и подлежащую соединительную ткань с кровеносными сосудами, нервными окончаниями и подкожной жировой клетчаткой, т.е. дерму. Исключение составляют тотальные препараты, например пленчатый препарат «Однослойный плоский эпителий - мезотелий (сальник кролика)», а также мазки крови и костного мозга, представляющие собой строго определенный тип ткани.

Гистологические препараты окрашиваются специальными красителями, которые могут служить маркерами отдельных видов тканей. Большинство гистологических красителей имеют свойства кислых (оранж G, эозин, кислый фуксин) или основных (азуры, толуидиновый синий, метиленовый синий, гематоксилин) соединений и формируют электростатические связи с ионизируемыми радикалами тканей $[31$, с. $6 ; 33$, с. $16 ; 34$, с. 16-17]. Наибольшее распространение получила комбинированная окраска гистологических препаратов с помощью основного красителя гематоксилина и кислого красителя эозина, при этом базофильные структуры, например ядра клеток, окрашиваются в сине-голубой цвет, а цитоплазма и неклеточные компоненты - в розовый цвет. Такой способ окрашивания характерен для гистологических срезов эпителия, собственно соединительных и мышечных тканей. Существуют красители, способные специфически связываться с химическими компонентами тканей или растворяться в них. В липидных каплях адипоцитов растворяется липофильный краситель судан III (обусловливает желтооранжевую окраску однокапельных адипоцитов), что может служить маркером для выявления белой жировой ткани при микроскопировании тотального препарата сальника. Миелиновые нервные волокна (расщепленный препарат седалищного нерва) обрабатывают осмиевой кислотой, которая специфически окрашивает миелиновую оболочку в черный цвет изза наличия в ней большого количества липидов. Такой метод выявления клеточных и тканевых структур, основанный на их способности удерживать или восстанавливать соли тяжелых металлов (серебро, свинец, осмий, золото), называется импрегнацией. Наряду с этим существуют тотальные неокрашенные гистологические препараты, например «Грубоволокнистая костная ткань (жаберная крышка селедки)».

Определение гистологического препарата, т.е. типа и вида ткани, - важный, но не единственный этап выполнения практического задания в кабинете «Биология человека» (9 класс). Как правило, участникам олимпиады предлагаются задания по морфофункциональной характеристике гистологических объектов, требующих знания особенностей структурно-функциональной организации исследуемых тканей. Хорошим подспорьем для практического изучения структурно-функциональной организации тканей животных послужат руководство к лабораторным занятиям по гистологии с основами эмбриологии А.И. Новикова, Е.С. Святенко (1984) и атлас по гистологии и эмбриологии И.В. Алмазова и Л.С. Сутулова (1978) [35; 36] и ряд более современных источников [33; 34; 37 и др.].

В практическое задание кабинета «Биология человека» (9 класс) может входить и зарисовка основных (характерных) структурных элементов тканей животных, представленных на микропрепаратах. Такое задание позволяет проверить и оценить умение школьников «читать» гистологические препараты, понимать общность и своеобразие структурной организации животных тканей [32, с. 216; 35, с. 5-6]. Нужно отметить, что благодаря прорисовке препаратов происходит более глубокое восприятие и запоминание фактического материала. При зарисовке гистологического объекта необходимо уделить внимание следующим моментам: 1) сначала нужно рассмотреть микропрепарат на малом увеличении и выбрать типичные детали, которые затем рассмотреть при большом увеличении, т.е. сначала на рисунок нужно нанести основные элементы препарата и лишь потом прорисовать детали; 2) соблюдать соотношения в размерах отдельных частей объекта; 3) структуры, разрезанные продольно или поперечно, мысленно воссоздать в объемном виде; 4) постараться воспроизвести все типы клеток и неклеточных структур, присутствующих на микропрепарате. 
Ефимова Н.В., Шилкова Т.В., Соколова Т.Л.

Совершенствование содержания подготовки школьников к практическому туру...

13.00 .00 - педагогические науки

Варианты заданий практического тура регионального этапа Всероссийской олимпиадь школьников по биологии (кабинет «Биология человека», 9 класс)

Задание 1. Вам предлагается 2 гистологических препарата*. Определите представленные на них ткани и заполните таблицу в матрице ответов (табл. 1). * - изображения гистологических объектов на «слепых» микропрепаратах представлены на рис. 1.

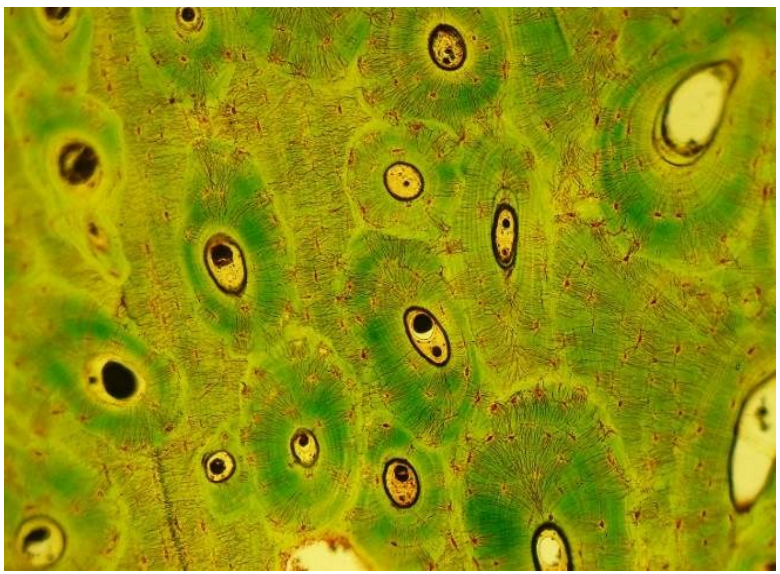

Препарат 1.1. Пластинчатая костная ткань поперечный срез диафиза трубчатой кости (окраска тионин-пикриновой кислотой)

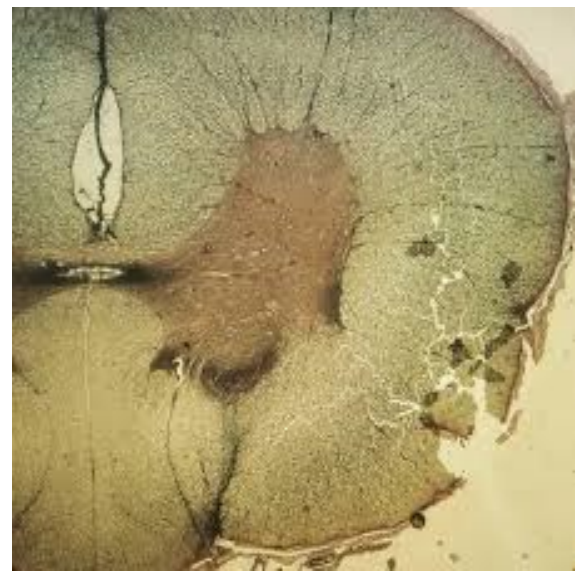

Препарат 1.2. Мультиполярные нейроны поперечный срез спинного мозга (окраска по методу Кахаля, импрегнация серебром)

Рисунок 1 - Гистологические объекты, представленные на «слепых» микропрепаратах задания 1

Таблица 1 - Матрица ответов задания 1

\begin{tabular}{|c|l|l|}
\hline $\begin{array}{c}\text { № пре- } \\
\text { парата }\end{array}$ & \multicolumn{1}{|c|}{$\begin{array}{c}\text { Название тканей } \\
\text { (вписать) }\end{array}$} & \multicolumn{1}{c|}{\begin{tabular}{c}
\multicolumn{1}{c}{ Обоснование ответа } \\
(отличительные морфологические признаки ткани)
\end{tabular}} \\
\hline \multirow{2}{*}{1} & $\begin{array}{l}\text { Соединительные } \\
\text { (скелетные) ткани. } \\
\text { Пластинчатая кост- } \\
\text { ная ткань } \\
\text { (поперечный срез) }\end{array}$ & $\begin{array}{l}\text { - большое количество строго структурированного межклеточного веще- } \\
\text { ства, однотипные клетки; } \\
\text { - остеоны (системы концентрических костных пластин); } \\
\text { - гаверсовы каналы; } \\
\text { - вставочные (интерстициальные) костные пластинки; } \\
\text { - отростчатые остеоциты в костных лакунах. }\end{array}$ \\
\hline \multirow{2}{*}{2} & $\begin{array}{l}\text { Нервная ткань. } \\
\text { Спинной мозг } \\
\text { (поперечный срез) }\end{array}$ & $\begin{array}{l}\text { - белое вещество спинного мозга; } \\
\text { - серое вещество спинного мозга (в виде бабочки); } \\
\text { - крупные мультиполярные мотонейроны (передние рога спинного мозга); } \\
\text { - нейрофибриллы. }\end{array}$ \\
\hline
\end{tabular}

Задание 2. Вам предлагается 2 гистологических препарата*. Определите представленные на них ткани и заполните таблицу в матрице ответов (табл. 2). * - изображения гистологических объектов на «слепых» микропрепаратах представлены на рис. 2.

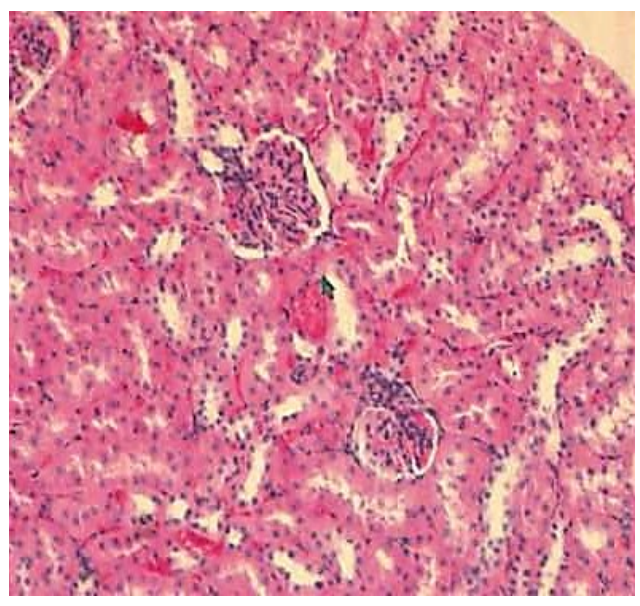

Препарат 2.1. Однослойный кубический эпителий - срез коркового вещества почки (окраска гематоксилин - эозином)

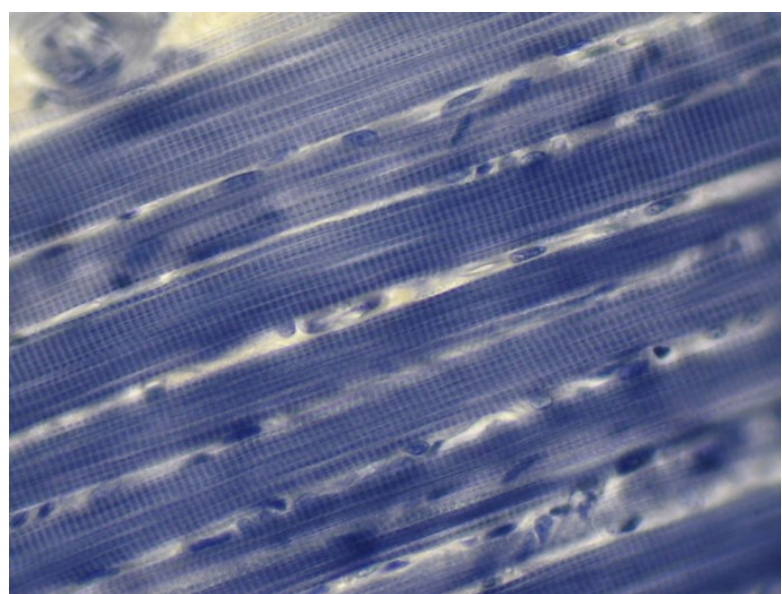

Препарат 2.2. Скелетные мышечные волокна срез продольной мышцы языка (окраска железным гематоксилином)

Рисунок 2 - Гистологические объекты, представленные на «слепых» микропрепаратах задания 2 
Таблица 2 - Матрица ответов задания 2

\begin{tabular}{|c|c|c|}
\hline $\begin{array}{l}\text { № пре- } \\
\text { парата }\end{array}$ & $\begin{array}{l}\text { Название тканей } \\
\text { (вписать) }\end{array}$ & $\begin{array}{c}\text { Обоснование ответа } \\
\text { (отличительные морфологические признаки и функции ткани) }\end{array}$ \\
\hline 1 & $\begin{array}{l}\text { Эпителиальные ткани. } \\
\text { Однослойный } \\
\text { кубический } \\
\text { эпителий почки }\end{array}$ & $\begin{array}{l}\text { - клетки кубической формы организованы в пласт, в котором практиче- } \\
\text { ски отсутствует межклеточное вещество и сосуды; } \\
\text { - клеточный пласт формирует сферические структуры (собирательные } \\
\text { канальцы нефрона), отграниченные от соединительной ткани базаль- } \\
\text { ной мембраной (пластинкой). } \\
\text { Функция ткани: выделительная (образование мочи). }\end{array}$ \\
\hline 2 & $\begin{array}{l}\text { Мышечная ткань. } \\
\text { Скелетная } \\
\text { поперечнополосатая } \\
\text { мышечная ткань }\end{array}$ & $\begin{array}{l}\text { - поперечнополосатая исчерченность мышечных волокон; } \\
\text { - пучки мышечных волокон в продольном и поперечном разрезах; } \\
\text { - многочисленные ядра по периферии мышечных волокон (симпласти- } \\
\text { ческое происхождение); } \\
\text { - прослойки соединительной ткани (эндомизий); } \\
\text { - жировые клетки. } \\
\text { Функция ткани: двигательная. }\end{array}$ \\
\hline
\end{tabular}

Задание 3. Вам предлагается 2 гистологических препарата*. Определите представленные на них ткани и заполните таблицу в матрице ответов (табл. 3 ). * - изображения гистологических объектов на «слепых» микропрепаратах представлены на рис. 3.

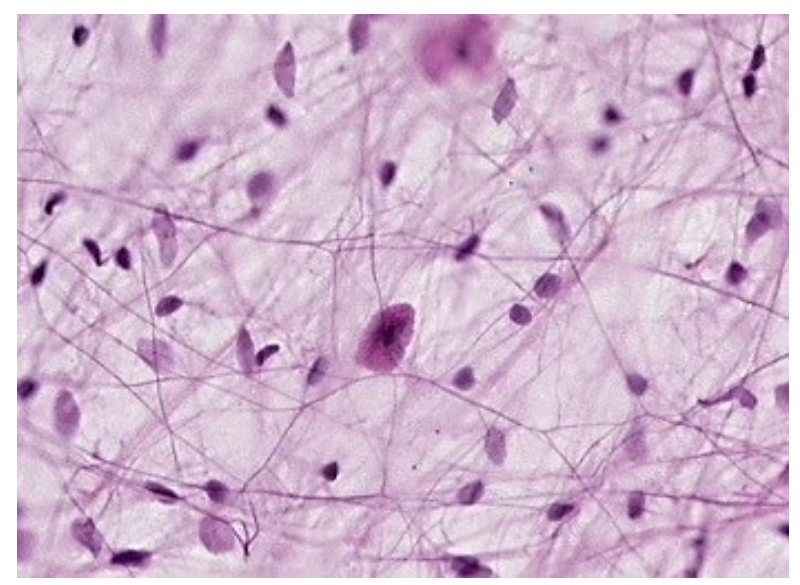

Препарат 3.1. Рыхлая соединительная ткань подкожная соединительная ткань кролика (окраска железным гематоксилином)

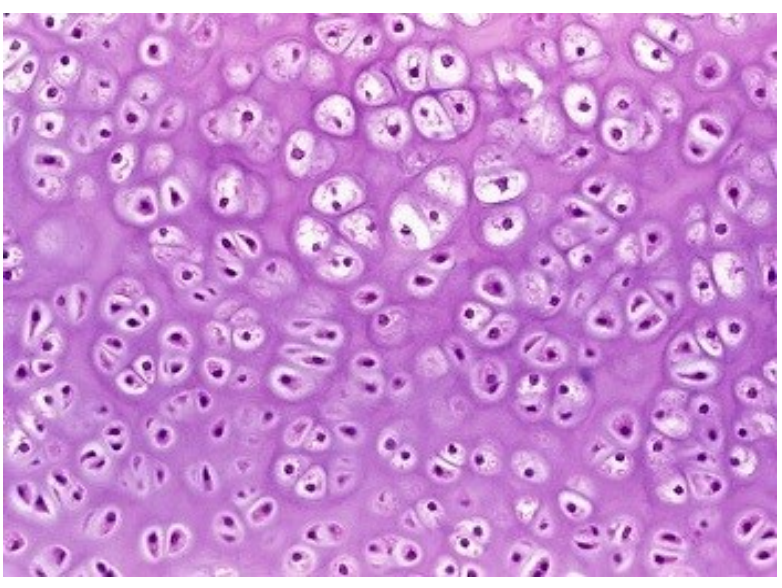

Препарат 3.2. Гиалиновый (стекловидный) хрящ ребра кролика (окраска гематоксилин-эозином)

Рисунок 3 - Гистологические объекты, представленные на «слепых» микропрепаратах задания 3

Таблица 3 - Матрица ответов задания 3

\begin{tabular}{|c|c|c|c|}
\hline $\begin{array}{c}\text { № пре- } \\
\text { парата }\end{array}$ & $\begin{array}{c}\text { Название тканей (вписать); рисунок, } \\
\text { соответствующий гистологическому препарату }\end{array}$ & $\begin{array}{l}\text { Обоснование ответа (отличительные } \\
\text { морфологические признаки ткани) }\end{array}$ \\
\hline подкинительные ткани. Рыхлая соединительная ткань - &
\end{tabular}


Ефимова Н.В., Шилкова Т.В., Соколова Т.Л.

\begin{tabular}{|c|c|c|}
\hline $\begin{array}{l}\text { № пре- } \\
\text { парата }\end{array}$ & $\begin{array}{c}\text { Название тканей (вписать); рисунок, } \\
\text { соответствующий гистологическому препарату }\end{array}$ & $\begin{array}{c}\text { Обоснование ответа (отличительные } \\
\text { морфологические признаки ткани) }\end{array}$ \\
\hline 2 & $\begin{array}{l}\text { Соединительные ткани. Гиалиновый (стекловидный) } \\
\text { хрящ ребра кролика. }\end{array}$ & $\begin{array}{l}\text { - надхрящница; } \\
\text { - много межклеточного (основного) } \\
\text { вещества; } \\
\text { - хондробласты; } \\
\text { - хондроциты (изогенные группы } \\
\text { клеток); } \\
\text { - капсулы хрящевых клеток }\end{array}$ \\
\hline
\end{tabular}

\section{Заключение}

Таким образом, практический тур регионального этапа Всероссийской олимпиады школьников по биологии (кабинет «Биология человека», 9 класс) требует глубокого знания теоретических основ гистологии и умения применять эти знания на практике, а именно навыков работы со световым микроскопом с целью определения и описания гистологических микропрепаратов. В связи с этим школьникам и учителям биологии при подготовке к олимпиаде необходимо систематизировать и углублять теоретические знания по гистологии, полученные в школьном курсе биологии, а также уделить достаточное внимание формированию практических умений по микроскопированию и описанию гистологических объектов.

\section{Список литературы:}

1. Богоявленская Д.Б. Рабочая концепция одаренности // Вопросы образования. 2004. № 2. С. 46-68.

2. Дятлова К.Д., Синицына Ю.В. Биологические олимпиады Нижегородского университета как средство профессиональной ориентации и профессионального отбора школьников // Вестник Нижегородского университета им. Н.И. Лобачевского. Серия: Социальные науки. 2017. № 4 (48). С. 175-181.

3. Пасько Т.Б. Система поиска и поддержки одаренных школьников в рамках реализации ФГОС начального общего образования // Образование и воспитание. 2017. № 1 (11). С. 11-14.

4. Репина Е.Г. Студенческое олимпиадное движение как инструмент поиска одаренной молодежи и педагогической работы с ней: принципы организации и опыт проведения // Самарский научный вестник. 2017. Т. 6, № 3 (20). С. 297-302.

5. Тарасенко Ю.А. Роль предметной олимпиады в формировании профессиональных компетенций // Образование и воспитание. 2017. № 1. С. 50-54.

6. Roy P. Gifted education in India // Cogent Education. 2017. Vol. 4, Is. 1. P. 1-18. DOI: 10.1080/2331186X.2017. 1332815.

7. Алексеева О.В. Прогрессивные направления магистерской подготовки в педагогическом вузе // Наука и школа. 2018. № 2. С. 9-13.

8. Баковецкая О.В., Камаева С.А., Калыгина Т.А., Клейменова Ю.Ю., Царева О.А., Терехина А.А. Биологическая олимпиада как вектор интеграции школы и медицинского вуза [Электронный ресурс] // Современные проблемы науки и образования. 2018. № 4. http://science-education.ru/ru/article/view?id=27857.
9. Национальная образовательная инициатива «Наша новая школа» [Электронный ресурс] // http://минобрнауки.рф/документы/1450.

10. Приказ Министерства образования и науки Российской Федерации от 18 ноября 2013 г. № 1252 г. «Об утверждении Порядка проведения всероссийской олимпиады школьников» [Электронный ресурс] // http://rg.ru/2014/01/ 29/olimpiadi-dok.html.

11. Акимова Е.И., Мурашев В.В. Роль московской олимпиады школьников по биологии в основном общем образовании в свете новых стандартов ФГОС // Актуальные проблемы гуманитарных и естественных наук. 2014. № 12-3. С. 62-69.

12. Malcolm A.D.B., Day G. The role of the IOB in the future of biological education // Journal of Biological Education. 2004. Vol. 38, Is. 4. P. 156-157. DOI: 10.1080/00219266.2004.9655932.

13. O'Kennedy R., Burke M., van Kampen P., James P., Cotter M., Browne W.R. The First EU Science Olympiad (EUSO): a model for science education // Journal of Biological Education. 2005. Vol. 39, Is. 2. P. 58-62. DOI: 10.1080/00219266.2005.9655962.

14. Эрастов Е.Р., Стельникова И.Г. Роль олимпиады по нормальной анатомии в повышении мотивации изучения предмета // Морфология. 2006. Т. 129, № 3. С. 97-98.

15. Evtimova S., Trakiiska K. The National Biology Competition: Criteria for Assessing Students' Knowledge and Skills // Biotechnology \& Biotechnological Equipment. 2009. Vol. 23, sup. 1. P. 50-52. DOI: 10. 1080/13102818.2009.10818363.

16. Дятлова К.Д. Предметные олимпиады как способ развития познавательной активности школьников // Школа будущего. 2012. № 3. С. 56-61.

17. Dierks P.O., Höffler T.N., Parchmann I. Profiling interest of students in science: Learning in school and beyond // Research in Science \& Technological Education. 2014. Vol. 32, Is. 2. P. 9-114. DOI: 10.1080/ 02635143.2014 .895712$.

18. Blankenburg J.S., Höffler T.N., Peters H., Parchmann I. The effectiveness of a project day to introduce sixth grade students to science competitions // Research in Science \& Technological Education. 2016. Vol. 34, Is. 3. P. 342-358. DOI: 10.1080/02635143.2016.1222361.

19. Feng A.X., Campbell J.R., Verna M.A. The Talent Development of American Physics Olympians // Gifted and Talented International. 2001. Vol. 16, Is. 2. P. 108-114. DOI: 10.1080/15332276.2001.11672972.

20. Campbell J.R., Walberg H.J. Olympiad studies: Competitions provide alternatives to developing talents 
Ефимова Н.В., Шилкова Т.В., Соколова Т.Л.

that serve national interests // Roeper Review. 2010. Vol. 33, Is. 1. P. 8-17. DOI: 10.1080/02783193.2011.530202.

21. Пискун А.А. Разработка методического сопровождения учащихся при подготовке к участию во Всероссийской олимпиаде школьников по биологии // Актуальные проблемы методики преподавания биологии, химии и экологии в школе и вузе: сборник материалов междунар. науч.-практ. конф. 27-29 октября 2016, Москва. М.: Московский гос. обл. ун-т, 2016. C. $180-182$

22. Волошина М.А. Опыт проведения регионального этапа олимпиады школьников по биологии в Новосибирском государственном университете // Вестник Новосибирского государственного университета. Серия: Педагогика. 2010. Т. 12, № 2. С. 63-72.

23. Шибкова Д.3. Общие рекомендации по подготовке к теоретическому туру олимпиады // Методические рекомендации педагогам общеобразовательных учреждений по организации олимпиад по биологии. Челябинск: Изд-во ИИУМЦ «Образование», 2008. C. 14-19.

24. Асылбекова Г.Е., Алиясова В.Н., Болдишор И.В. Основы подготовки школьников к олимпиаде по биологии // American Scientific Journal. 2016. № 8 (8). C. 4-7.

25. Ефимова Н.В., Чучкина Р.Ф. Методические указания к выполнению заданий по морфологии и гистологии практического тура школьной биологической олимпиады // Методические рекомендации педагогам общеобразовательных учреждений по организации олимпиад по биологии. Челябинск: Изд-во ИИУМЦ «Образование», 2008. С. 31-39.

26. Ефимова Т.М., Дмитриева Т.А. Вопросы биологии растений на практическом туре Всероссийской олимпиады школьников по биологии // Актуальные проблемы методики преподавания биологии, химии и экологии в школе и вузе: сборник материалов междунар. науч.-практ. конф. 27-29 октября 2016, Москва. М.: Московский гос. обл. ун-т, 2016. С. 323-326.

27. Ефимова Т.М., Дмитриева Т.А. Использование индивидуально-групповой организации учебно-иссле- довательской деятельности обучающихся при их подготовке к участию в олимпиаде по биологии // Педагогическое образование и наука. 2016. № 6. С. 33-38.

28. Швецов Г.Г. Создание методической системы подготовки школьников к участию в предметной олимпиаде по биологии // Педагогическое образование и наука. 2015. № 3. С. 17-20.

29. Швецов Г.Г. К вопросу о разработке методической системы подготовки школьников к участию в предметной олимпиаде по биологии // Актуальные проблемы методики преподавания биологии, химии и экологии в школе и вузе: сборник материалов междунар. науч.-практ. конф. 27-29 октября 2016, Москва. М.: Московский гос. обл. ун-т, 2016. С. 102-104.

30. Швецов Г.Г. Организация подготовки школьников к участию в предметной олимпиаде как элемент совершенствования методической работы учителя биологии // Педагогическое образование и наука. 2017. № 5. С. 16-19.

31. Практикум по гистологии, цитологии и эмбриологии: учеб. пособие / под ред. Н.А. Юриной, А.И. Радостиной. М.: Изд-во УДН, 1989. 253 с.

32. Тейлор Д., Грин Н., Стаут У. Биология: В 3-х т. Т. 1: Пер. с англ. / под ред. Р. Сопера. М.: Мир, $2005.454 \mathrm{c}$

33. Жункейра Л.К., Карнейро Ж. Гистология: атлас: учеб. пособие / пер. с англ. под ред. В.Л. Быкова. М.: ГЭОТАР-Медиа, 2009. 576 с.

34. Быков В.Л. Цитология и общая гистология (функциональная морфология клеток и тканей). СПб.: СОТИС, 2007. 520 с.

35. Новиков А.И., Святенко Е.С. Руководство к лабораторным занятиям по гистологии с основами эмбриологии. М.: Просвещение, 1984. 168 с.

36. Алмазов И.В., Сутулов Л.С. Атлас по гистологии и эмбриологии. М.: Медицина, 1978. 544 с.

37. Кюнель В. Цветной атлас по цитологии, гистологии и микроскопической анатомии / пер. с англ. Е. Погосян. М.: АСТ: Астрель, 2007. 533 с.

\title{
IMPROVING THE CONTENT OF SCHOOLCHILDREN TRAINING FOR THE PRACTICAL ROUND OF THE REGIONAL STAGE OF THE ALL-RUSSIAN BIOLOGICAL OLYMPIAD
}

\author{
Efimova Natalya Vladimirovna, doctor of biological sciences, \\ professor of General Biology and Physiology Department \\ Shilkova Tatyana Viktorovna, candidate of biological sciences, \\ associate professor of General Biology and Physiology Department \\ Sokolova Tatyana Leonidovna, candidate of biological sciences, \\ associate professor of General Biology and Physiology Department \\ South Ural State Humanitarian Pedagogical University (Chelyabinsk, Russian Federation)
}

\footnotetext{
Abstract. One of the tasks of the modern educational system is to develop and support talented young people. One way of it could be the subject Olympiads for schoolchildren, which contribute to the professional orientation of students and their future success in life increasing students' interest in science as well as developing their creative potential and cognitive activity. The experience of carrying out various stages of the All-Russian Biological Olympiad for schoolchildren in Biology showed that in order to achieve high results, participants of the Olympiad need a methodically sound system of training camps and advice from specialists in various fields of Biology. The paper summarizes long-term experience of organizing a practical tour of the regional stage of the All-Russian Olympiad for schoolchildren in Biology at the department of General biology and Physiology of the South Ural State Humanitarian Pedagogical University. The authors present methodological recommendations aimed at improving schoolchildren training for a practical tour of the regional stage of the All-Russian Olympiad in Biology (room «Human Biology», grade 9), including a description of typical mistakes made by participants in the Olympiad, an algorithm for performing practical tasks on microscopy of histological preparations, criteria for differentiating histological objects, examples of Olympiad tasks with a matrix of answers.

Keywords: National educational initiatives; All-Russian School Olympiad in Biology; practical round of the Olympiad; Olympiad practical tasks in histology; guidelines; work with gifted children; schoolchildren training to participate in subject Olympiad in Biology.
} 